Hal. $400-412$

\title{
ANALISIS FINANCIAL DISTRESS DAN BEBERAPA VARIABEL PREDIKTORPADA SEKTOR PERBANKAN DI INDONESIA
}

\author{
Sumani \\ Fakultas Ekonomi dan Bisnis Universitas Jember \\ sumani.feb.mgt.d3ak@gmail.com \\ Andri Setiawan \\ Fakultas Ekonomi dan Bisnis Universitas Jember
}

\begin{abstract}
The Purpose of this study is (1) to analyze financial distress as predictor variables of financial difficulty levels banking which is listing on the Stock Exchange $(B E I)$, and (2) determine the financial ratios, including CAR, ROE, NPL, NIM, LDR, $R O A, B O P O$, and the primary reserve as predictor variables of financial distress in banking sector which is listing on the BEl. The population of this study were 38 banks which is listed on the BEl until December 31th, 2014. Number of samples were 30 banks by purposive sampling technique. The analysis tool of study used Logit regression because of dependent variable was dummy variable and the independent variables were a combination of metric and non-metric. The results showed (1) banks were listed on the BEI has good performance (financial difficulties at low levels), the analysis result of financial distress by using multiple predictor variables, such as CAR, ROE, NPL, NIM, LDR, BOPO and reserves' primary GWM has good average value where is level of accuracy (97.2) in classifying the bank's financial difficulties; (2) The hypothesis testing showed a number of variables such as CAR, ROE, NIM, LDR, and $B O P O$ were not significant as a predictor of financial distress in banking where listed on the BEl. However, NPL and reserves' primary GWM were significant variable as predictor of financial distress in banking where listed on the BEI.
\end{abstract}

Keywords: Reserves' primary GWM, Non-Performing Loan, Financial Distress

Abstrak: Penelitian ini bertujuan, yaitu: (1) menganalisis variabel prediktor tingkat kesulitan keuangan (financial distress) perbankan yang listing di BEI; (2) mengetahui rasio keuangan, meliputi CAR, ROE, NPL, NIM, LDR, BOPO, dan GWM primer sebagai variabel prediktor terhadap kesulitan keuangan (financial distress) sektor perbankan yang listing di BEI. Populasi penelitian ini adalah bank yang terdaftar di BEI sampai tanggal 31 Desember 2014, yaitu sebanyak 38 bank. Penentuan pengambilan dalam penelitian ini menggunakan metode purposive sampling dengan jumlah sampel sebanyak 30 bank. Alat analisis yang digunakan adalah regresi logit dikarenakan variabel terikatnya berupa variabel dummy (non-metrik) dan variabel bebasnya berupa kombinasi antara metrik dan non-metrik. Hasil penelitian: (1) perbankan yang listing di BEI memiliki kinerja yang baik (kesulitan keuangan pada level rendah), sebab berdasarkan analisis financial distress dengan menggunakan beberapa variabel predictor yang meliputi : CAR, ROE, NPL, NIM, LDR, BOPO dan GWM primer memiliki nilai rata-rata yang bagus, dengan tingkat akurasi dalam mengklasifikasikan kesulitan keuangan bank hingga 97,2 (baik); (2) Pengujian hipotesis menunjukkan bahwa variabel CAR, ROE, NIM, LDR, dan BOPO tidak signifikan sebagai prediktor terhadap financial distress perbankan yang listing di BEI. Namun variabel NPL dan GWM primer signifikan sebagai prediktor financial distress perbankan yang listing di BEI.

Kata Kunci: Giro Wajib Minimum, Non-Performing Loan, Financial Distress. 


\section{Pendahuluan}

Dunia perbankan nasional memiliki tingkat pertumbuhan dan kompleksitas usaha yang sangat tinggi, sejalan dengan hal tersebut maka risiko yang dihadapi akan semakin meningkat. Risiko yang dihadapi perbankan secara signifikan memengaruhi tingkat kesehatan perbankan, khususnya kondisi kesulitan keuangan bank. Dalam situs Otoritas Jasa Keuangan,risiko perbankan di Indonesia antara lain yakni: risiko kredit, risiko pasar, risiko likuiditas, risiko operasional, risiko hukum, risiko reputasi, risiko strategik, dan risiko kepatuhan. Semakin banyaknya risiko pada bank, dapat membuat peluang bank mengalami kesulitan keuangan atau financial distress. Financial distress merupakan gejala awal dari kebangkrutan perusahaan (Kurniasari, 2013). Laporan keuangan merupakan sumber informasi yang dapat dijadikan prediktor dalam menilai kondisi kesehatan bank dan kesulitan keuangan bank. Oleh karena itu diperlukan suatu sistem untuk menganalisis kinerja keuangan melalui laporan keuangan untuk mengetahui adanya kemungkinan bank tersebut mengalami kesulitan keuangan atau financial distress yang berakibat pada kebangkrutan (Kurniasari, 2013).

Pengukuran prediktor kesulitan keuangan pada perbankan dapat dilakukan dengan cara menganalisis laporan yang dikeluarkan oleh bank yang bersangkutan. Analisis laporan keuangan merupakan suatu cara untuk mengetahui posisi keuangan beserta hasil yang telah dicapai dari strategi - strategi manajemen perbankan pada masa yang telah tercapai. Melalui laporan keuangan yang dianalisis publik dapat melihat, menilai dan dasar pengambilan keputusan dengan hasil analis.

Peraturan Bank Indonesia No. 14/14 /PBI/2012 tentang transparansi dan publikasi laporan bank menetapkan bahwa beberapa manfaat yang dapat dicapai melalui transparansi informasi kondisi keuangan dan kinerja bank kepada publik, antara lain: (i) sebagai dasar penetapan keputusan oleh pelaku pasar dan publik; (ii) meningkatkan kredibilitas bank dan kepercayaan masyarakat atas lembaga perbankan nasional; (iii) memperlihatkan kemampuan bank untuk memantau dan mengelola risiko; dan (iv) mengurangi ketidakpastian pasar (market uncertainty) serta kesenjangan informasi (assymetric information).

Ramadhani dan Lukviarman (2009:17) mengatakan bahwa, financial distress merupakan situasi dimana arus kas operasi perusahaan tidak memadai untuk melunasi kewajiban - kewajiban lancar (seperti hutang dagang atau beban bunga) dan perusahaan terpaksa melakukan tindakan perbaikan. Analisis laporan keuangan diberlakukan guna mendapatkan tanda - tanda potensi kebangkrutan pada perbankan, sehingga dapat segera diatasi oleh pihak manajemen bank.

Pelopor studi kesulitan keuangan (financial distress) adalah Beaver (2006), dan beberapa tahun kemudian dilanjutkan oleh Altman (1968). Beaver dan Altman 
menggunakan data - data akuntansi dari neraca dan laporan rugi laba perusahaan, dalam bentuk rasio-rasio keuangan sehingga digunakan sebagai variabel prediktor financial distress. Di Indonesia beberapa peneliti yang melakukan penelitian terhadap financial distress seperti Wilopo (2011), Santoso, Hadad, dan Sarwedi (2008), Almilia \& Winny Herdiningtyas (2005), Penny Mulyaningrum (2008), Lestari (2009), Prasetyo (2011), dan Vidyarto Nugroho (2012).

Penelitian kesulitan keuangan dan menganalisis rasio keuangan dapat dilakukan dengan memperhatikan: Capital Adequacy Ratio (CAR), Return On Equity (ROE), Non Performing Loan (NPL), Net Interst Margin (NIM), Loan To Deposit Ratio (LDR), biaya operasional terhadap pendapatan operasional (BOPO), dan Giro Wajib Minimum (GWM) Primer. Hal ini diperkuat dengan beberapa peneliti yang meneliti kesulitan keuangan diantaranya: Almilia dan Herdiningtyas (2009) meneliti menggunakan rasio - rasio keuangan yaitu CAR, ATTM, APB, NPL, PPAP terhadap Aktiva Produktif, Pemenuhan PPAP, ROA, ROE, NIM, BOPO, LDR. Hasil penelitian tersebut memperlihatkan CAR, BOPO memiliki pengaruh yang signifikan terhadap prediksi kondisi bermasalah. Penni Mulyaningrum (2008) meneliti sejumlah variabel rasio keuangan bank, yaitu: CAR, LDR, NPL,BOPO, ROA, ROE, NIM untuk memprediksi kebangkrutan bank di Indonesia. Menggunakan alat analisis regresi logit. Hasil uji multivarian memperlihatkan bahwa rasio LDR berpengaruh signifikan terhadap profitabilitas kebangkrutan.

Tujuan Penelitian dalam penelitian ini, yaitu: (1) menganalisis variabel prediktor financial distress perbankan yang listing di BEI; (2) mengetahui rasio keuangan, meliputi variabel CAR, ROE, NPL, NIM, LDR, BOPO, dan GWM primer sebagai prediktor terhadap financial distress sektor perbankan yang listing di BEI

\section{Metodologi}

\section{Rancangan Penelitian}

Penelitian ini merupakan jenis penelitian diskriptif kuantitatif yang menganalisis kausalitas antara rasio - rasio keuangan yaitu Capital Adequacy Ratio (CAR), Return On Equity (ROE), Non Performing Loan (NPL), Net Interst Margin (NIM), Loan To Deposit Ratio (LDR), biaya operasional terhadap pendapatan operasional (BOPO), dan Giro Wajib Minimum (GWM) Primer terhadap kesulitan keuangan bank yang terdaftar di BEI.

\section{Populasi dan Sampel}

Populasi dalam penelitian ini adalah bank yang terdaftar di BEI periode 2010 - 2014. Jumlah bank yang terdaftar di BEl sampai tanggal 31 Desember 2014 sebanyak 36 bank. Penentuan pengambilan jumlah sampel yang digunakan dalam penelitian ini didasarkan pada metode purposive sampling, artinya teknik pengambilan sampel dengan melakukan 
pertimbangan dan kriteria tertentu yang disesuaikan tujuan penelitian. Jumlah sampel dalam penelitian ini sebanyak 30 bank.

\section{Definisi Operasional Variabel dan Skala Pengukuran Variabel}

1. Variabel Terikat (Dependent variable)

Variabel terikat dalam peneitian ini adalah kesulitan keuangan (financial distress). Penilaian yang digunakan dalam memprediksi kesulitan keuangan suatu bank diwakili oleh bank yang ijinnya dicabut oleh Bank Indonesia, atau bank yang melakukan merger, dan atau bank yang mengalami kerugian berturut - turut selama minimal dua tahun (Almilia dan Kristijadi, 2003). Variabel terikat yang digunakan dalam penelitian ini merupakan variabel dummy poin 1 untuk bank dalam kondisi kesulitan keuangan (financial distress) dan 0 untuk bank yang tidak dalam kondisi kesulitan keuangan (financial distress). Skala pengukurannya menggunakan skala nominal karena merupakan variabel dummy.

2. Variabel Bebas (Independent Variable)

a. Capital Adequacy Ratio (CAR)

Capital adequacy ratio (CAR) adalah rasio yang memperlihatkan seberapa besar jumlah seluruh aktiva bank yang mengandung risiko (kredit, penyertaan, surat berharga, tagihan pada bank lain) ikut dibiayai dari modal sendiri disamping memperoleh dana dari sumber-sumber di luar bank. Skala pengukuran variabel CAR menggunakan skala rasio.

b. Return On Equity (ROE)

Return on Equity (ROE) adalah perbandingan antara laba bersih bank dengan modal sendiri. ROE adalah indikator penting yang perlu di cermati investor yang keterkaitannya dalam memperoleh laba bersih dan mengenai deviden. Skala pengukuran variabel ROE menggunakan skala rasio.

c. Non Performing Loan (NPL)

Non performing loan (NPL) merupakan rasio yang menunjukkan kemampuan manajemen bank dalam mengelola kredit bermasalah yang diberikan oleh bank. Skala pengukuran variabel NPL menggunakan skala rasio.

d. Net Interst Margin (NIM)

Net interst margin (NIM) merupakan rasio yang digunakan sebagai pengukur manajemen bank dalam mengelola aktiva produktifnya untuk menghasilkan pendapatan bunga bersih. Skala pengukuran variabel NIM menggunakan skala rasio.

e. Loan To Deposit Ratio (LDR)

Loan to Deposit Ratio (LDR)adalah rasio digunakan untuk menilai likuiditas suatu bank dengan cara membagi jumlah kredit yang diberikan oleh bank terhadap dana pihak ketiga. Skala pengukuran variabel LDR menggunakan skala rasio.

f. Biaya Operasional Terhadap Pendapatan Operasional (BOPO) 
Biaya Operasional Terhadap Pendapatan Operasional (BOPO) adalah rasio yang digunakan untuk mengukur kemampuan manajemen bank dalam mengendalikan biaya operasional terhadap pendapatan operasional. Skala pengukuran variabel BOPO menggunakan skala rasio.

g. Giro Wajib Minimum (GWM) Primer

GWM Primer adalah simpanan minimum yang wajib dipelihara oleh Bank dalam bentuk saldo Rekening Giro pada Bank Indonesia. Bank Indonesia menetapkan GWM Primer dalam rupiah sebesar $8 \%$ (delapan persen) dari DPK dalam rupiah.

\section{Metode Analisis Data}

\section{Statistik Deskriptif}

Statistik deskriptif menjelaskan besarnya nilai rata-rata, deviasi standar, nilai minimum, dan nilai maksimum untuk variabel-variabel kecuali variabel dummy. Nilai ratarata menunjukkan jumlah nilai seluruh observasi dibanding dengan jumlah observasi dari masing-masing dari rasio yang digunakan. Nilai minimum adalah nilai terendah dari seluruh observasi dan nilai maksimum adalah nilai tertinggi dari seluruh observasi. Sedangkan deviasi standar yang menunjukkan ukuran penyebaran data dari seluruh observasi (Ghozali, 2005).

\section{Uji Kelayakan Model Regresi Logit}

Kelayakan model regresi logit di uji dengan menggunakan Homer and Lemeshow'sGoodness of Fit Test menguji hipotesis nol bahwa data empiris cocok atau sesuai dengan model (tidak ada perbedaan antara model dengan data sehingga model dapat dikatakan fit). Jika nilai Homer and Lemeshow's Goodness of Fit Test sama dengan atau kurang dari 0,05 maka ada perbedaan yang signifikan antara model dengan nilai observasinya sehingga Goodness fit model tidak baik karena model tidak dapat memprediksi nilai observasinya. Jika nilai statistic Homer and Lemeshow's Goodness of Fit Test > 0,05 maka model mampu memprediksi nilai observasinya atau dapat dikatakan model diterima karena cocok dengan data observasinya (Ghozali, 2005).

\section{Uji Koefisien Determinasi}

Uji Koefisien Determinasi digunakan untuk mengetahui seberapa besar semua variabel independen secara bersamaan memengaruhi variabel dependen. Uji koefisien determinasi pada analisis regresi logit ini menggunakan uji Nagelkerke $R$ Square (Ghozali, 2006). Nilai Nagelkerke $R$ Squareberada diantara 0 sampai 1. Semakin tinggi nilai Nagelkerke $R$ Square, maka semakin besar variasi variabel independen mampu menjelaskan variabel dependen dalam model regresi. 


\section{Analisis Regresi Logit}

Menurut Ghozali (2009), Pengujian hipotesis dalam penelitian ini menggunakan regresi logit karena variabel terikatnya berupa variabel dummy (non-metrik) dan variabel bebasnya berupa kombinasi antara metrik dan non-metrik. Persamaan regresi logitdapat dinyatakan sebagai berikut:

$$
p_{i}=E\left(Y_{i}=1 \mid X_{i}\right)=\frac{1}{1+e^{-\left(\beta_{1}+\beta_{2} X_{i(t-1)}\right)}}
$$

keterangan:

$P_{i}$ : peluang bank ke-i kesulitan keuangan $(Y=1) ; 0 \leq P_{i} \leq 1$

Xi: variabel prediktor bank ke-i

$\mathrm{Zi}$ : fungsi linier variabel; $-\infty \leq \mathrm{Z}_{\mathrm{i}} \leq+\infty$

e : logaritma natural; $e=2,71828$

$\mathrm{n}$ : jumlah bank anggota popuasi survei

$\beta$ : koefisien regresi logit

\section{Uji Hipotesis}

Uji hipotesis penelitian ini menggunakan uji Wald. Uji Wald dalam regresi logit digunakan untuk menguji masing-masing parameter secara parsial. Langkah-langkah pengujian hipotesis adalah sebagai berikut :

a. Menentukan tingkat signifikansi

Tingkat signifikansi yang digunakan $95 \%$ dan $\alpha=5 \%$

b. Menentukan kriteria pengujian

Jika $p$-value> $\alpha$, maka H0 diterima

Jika $p$-value<a, maka $\mathrm{HO}$ ditolak

\section{Hasil dan Pembahasan}

\section{Hasil Analisa Data}

a. Uji Kelayakan Model Regresi Logit

Nilai statistik Hosmer and Lemeshow's Goodness of Fit Test sebesar 6,560 dan dengan signifikansi sebesar 0,585. Dalam output perhitungan sebesar 0,585 $>0,05$ menunjukkan bahwa tidak adanya perbedaan model dengan nilai observasinya hal ini juga berarti Ho diterima, sehingga model dapat memprediksi hasil berupa nilai dari observasi 
penelitian. Dengan kata lain bahwa model dapat diterima karena dapat memprediksi pengaruh antar variabel bebas terhadap variabel terikat dengan tingkat keyakinan $95 \%$.

b. Uji Koefisien Determinasi

Uji koefisien determinasi dalam penelitian ini menggunakan Nagelkerke $R$ Square. Pada tabel Nagelkerke $R$ Square diketahui memililiki nilai sebesar 0,373. Nilai yang dapat dilihat pada kolom Nagelkerke $R$ Square memiliki makna bahwa variabilitas variabel dependen yang dapat dijelaskan oleh variabilitas variabel independen sebesar $37,3 \%$. Dijelaskan pula bahwa 62,7\% variabilitas variabel dependen dijelaskan atau dipengarui oleh variabel independen lainnya.

c. Uji Model Statistik

Tabel 1 Signifikasi dan Koefisien Regresi

\begin{tabular}{|c|c|c|c|c|c|c|c|}
\hline & & $B$ & S.E. & Walc & Df & Sig. & $\operatorname{Exp}(B)$ \\
\hline & CAR & ,025 & 104 & ,056 & 1 & 813 & 1,025 \\
\hline & ROE &,- 025 & ,043 & ,337 & 1 & ,561 & ,975 \\
\hline & $\overline{N P L}$ & ,480 & 194 & 6,089 & 1 & ,014 & 1,616 \\
\hline Ctan 19 & $\overline{\mathrm{NIM}}$ & -,266 & ,226 & 1,388 & 1 & ,239 & ,766 \\
\hline & LDR & 024 & ,042 & ,336 & 1 & ,562 & 1,024 \\
\hline & BOPO & ,036 & ,070 & 257 & 1 & 612 & 1,036 \\
\hline & $\overline{\text { GWM }}$ &,- 900 & ,390 & 5,332 & 1 & ,021 & ,407 \\
\hline & Constar & $-1,355$ & 7,926 & ,029 & 1 & ,864 & ,258 \\
\hline
\end{tabular}

a. Variable(s) entered on step 1: CAR, ROE, NPL, NIM, LDR, BOPO, GWM.

Sumber: data diolah

Pada tabel 1 dapat dilihat variabel NPL dan GWM primer yang tingkat signifikansinya dibawah tingkat $\alpha=5 \%$, yaitu sebesar 0,014 untuk variabel $N P L$, dan 0,021 untuk variabel GWM primer. Tingkat signifikansi kedua variabel tersebut menjadikan Variabel NPL dan GWM primer dapat secara signifikan berpengaruh terhadap tingkat kesulitan keuangan. Variabel bebas lainnya belum cukup untuk memenuhi tingkat signifikansi yang ditentukan, sehingga hanya variabel NPL dan GWM primer yang dapat difungsikan dalam sebuah model regresi logit. Sebuah persamaan regresi logit dapat diperoleh melalui tabel 1 yakni sebagai berikut.

$$
p_{i}=\frac{1}{1+e^{-\left(-1,355+0,48 N P L_{(t-1)}-0,9 G W M_{(t-1)}\right)}}
$$

Pengujian model logit berdasarkan persamaan guna mengetahui atau menguji bagaimana hasil dari suatu sampel, jika diketahui estimator atau nilai konstannya. Model 
regresi yang telah diketahui dapat diketahui nilai estimatornya $\mathrm{Bo}=-1,355 ; \mathrm{NPL}=0,48$; dan GWM Primer= -0,9. Model Formula tersebut mempunyai nilai Chi-square sebesar 6,560, dengan nilai signifikansi sebesar 0,585 yang lebih besar dari $\alpha=5 \%$. Artinya, tidak ada perbedaan antara model dengan nilai observasinya sehingga dapat dikatakan model ini layak untuk digunakan. Keakuratan model regresi dapat mengklasifikasikan kesulitan keuangan atau financial distress bank hingga 97,2\%. Tingkat akurasi tersebut dapat dikatakan baik.

\section{Kondisi Financial Distress Bank di BEl (Sampel Penelitian)}

Sampel penelitian sebanyak 30 perusahaan perbankan yang terdaftar pada BEI periode 2010 - 2014, rata - rata mempunyai rasio CAR yang cukup baik karena berada di atas standarisasi OJK (Otoritas Jasa Keuangan). Artinya bank yang listing di BEI memiliki modal sendiri yang cukup terhadap aktiva tertimbang menurut resiko. Rasio ROE dari sampel yang diteliti memiliki rata - rata laba bersih positif. Artinya rata-rata bank (sampel penelitian) mampu menghasilkan laba yang cukup atas rata-rata ekuitas. Rasio NPL relatif rendah, hal itu menunjukkan bahwa bank tersebut memiliki sedikit kredit bermasalah.

Rasio LDR cukup baik, hal ini mengindikasikan bahwa perbankan tersebut memiliki likuiditas yang baik, dikarenakan prosentase kredit yang diberikan terhadap dana pinjaman pihak ketiga rendah. Rasio BOPO cukup baik, hal ini mengindikasikan bahwa bank tersebut memiliki kemampuan meminimalisir pengeluaran. Rasio ini merupakan perbandingan biaya operasional dengan pendapatan operasional, lain halnya jika biaya operasional besar namun tidak diimbangi dengan pendapatan operasionalnya maka prosentase rasio ini akan semakin tinggi. Rasio GWM Primer relative banyak, berarti bahwa cadangan Giro Wajib pada bank sentral tersebut relatif banyak.

\section{CAR sebagai prediktor kesulitan keuangan bank yang listed di BEI}

Variabel bebas CAR memiliki tingkat signifikansi lebih besar dari 0,05 yakni 0,813, hal ini berarti variabel CAR tidak segnifikan sebagai prediktor kesulitan keuangan pada perbankan yang terdaftar pada $\mathrm{BEI}$ ( $\mathrm{HO}$ diterima, $\mathrm{Ha}_{1}$ ditolak). Hal ini tidak konsisten dengan penelitian dari Almilia dan Winny Herdiningtyas (2005) serta Dendawijaya (2009), yang menyatakan rasio CAR mempunyai pengaruh signifikan terhadap kesulitan keuangan pada perbankan.

Rasio CAR memiliki koefisien regresi 0,025 hal ini menunjukkan bahwa rasio CAR berpengaruh positif terhadap kondisi kesulitan keuangan yang artinya semakin tinggi rasio CARkemungkinan bank dalam kondisi bermasalah semakin besar. Nilai positif pada koefisien regresi CAR tidak konsisten dengan penelitian dilakukan Almilia dan Winny Herdiningtyas (2005), tanda koefisien variabel CAR juga tidak sesuai dengan hipotesis yang 
diajukan (positif).Penelitian dengan rentang waktu yang lebih banyak atau jumlah sampel yang lebih banyak kemungkinan dapat memberikan hasil uji yang lebih akurat.

\section{$\underline{R O E}$ sebagai prediktor negatif kesulitan keuangan bank yang terdaftar di BEI}

Variabel bebas ROE memiliki tingkat signifikansi lebih besar dari 0,05, yakni 0,561. Hal ini berarti bahwa tidak signifikannya pengaruh ROE terhadap kesulitan keuangan pada perbankan yang terdaftar pada $\mathrm{BEI}$ ( $\mathrm{HO}$ diterima, $\mathrm{Ha}_{2}$ ditolak). Rasio $\mathrm{ROE}$ memiliki koefisien regresi $-0,025$ hal ini menunjukkan bahwa semakin rendah rasio ROE pada perbankankemungkinan bank dalam kondisi bermasalah semakin besar. Tanda koefisien variabel ROE sesuai dengan hipotesis yang diajukan (negatif), dan juga sesuai dengan penelitian dari Penny Mulyaningrum (2008) dan Dendawijaya (2009).

Implikasi ROE terhadap pihak manajemen perbankan diharapkan tetap memperhatikan ROE meskipun dalam penelitian ini ROE tidak signifikan, namun memiliki kesamaan koefisien tanda negatif. ROE digunakan untuk melihat efektifitas perusahaan dalam menghasilkan laba melalui modal sendiri.

\section{NPL sebagai prediktor positif kesulitan keuangan bank yang terdaftar di BEI}

Variabel bebas NPL memiliki tingkat signifikansi lebih rendah dari 0,05, yakni 0,014. Hal ini berarti bahwa signifikannya pengaruh NPL terhadap kesulitan keuangan pada perbankan yang terdaftar pada $\mathrm{BEI}$ ( $\mathrm{Ho}$ ditolak, $\mathrm{Ha}_{3}$ diterima). Hal ini konsisten dengan penelitian dari Prasetyo (2011), yang menyatakan bahwa rasio NPL mempunyai pengaruh positif dan signifikan terhadap probabilitas tingkat kesehatan bank.

NPL adalah rasio untuk mengukur kualitas kredit dengan menggunakan perbandingan antara kredit bermasalah dengan total kredit menurut Ganiarto dan Ibad dalam Penny Mulyaningrum (2008). Dahlan Siamat (2006:174) mengartikan NPL sebagai pinjaman yang mengalami kesulitan pelunasan akibat adanya faktor kesenjangan dan atau karena faktor eksternal dari luar kendali calon debitur, NPL dapat diukur dari kolektibilitasnya yaitu merupakan gambaran kondisi pembayaran pokok dan bunga pinjaman serta kemungkinan diterimanya kembali dana yang ditanamkan. Semakin tinggi rasio ini maka akan semakin buruk kualitas kredit bank yang menyebabkan jumlah kredit bermasalah semakin besar karena tingkat kesehatannya menurun. Kemungkinan suatu bank dalam kondisi bermasalah semakin besar (Almilia dan Winny Herdiningtyas, 2005)

\section{NIM sebagai prediktor negatif kesulitan keuangan bank yang terdaftar di BEI}

Variabel bebas NIM memiliki tingkat signifikansi lebih besar dari 0,05 yakni 0,239. Berarti bahwa tidak signifikannya pengaruh NIM terhadap kesulitan keuangan pada perbankan yang terdaftar pada $\mathrm{BEI}$ (Ho diterima, $\mathrm{Ha}_{4}$ ditolak). Hal ini tidak konsisten dengan penelitian dari Almilia dan Winny Herdiningtyas (2005) yang menyatakan rasio NIM mempunyai pengaruh signifikan terhadap kesulitan keuangan pada perbankan. Penny 
Mulyaningrum(2008) menyatakan, NIM yang negatif mengindikasikan terdapat bank yang memiliki margin bunga bersih sangat rendah

Rasio NIM memiliki koefisien regresi -0,266 hal ini menunjukkan bahwa rasio NIM berpengaruh negatif terhadap kondisi kesulitan keuangan yang artinya semakin rendah rasio NIMkemungkinan bank dalam kondisi bermasalah semakin besar. Nilai negatif pada koefisien regresi NIM konsisten dengan penelitian dilakukan Almilia dan Winny Herdiningtyas (2005) , tanda koefisien variabel NIM juga telah sesuai dengan hipotesis yang diajukan (negatif).

\section{LDR sebagai prediktor positif kesulitan keuangan bank yang terdaftar di BEI}

Variabel bebas LDR memiliki tingkat signifikansi lebih besar dari 0,05, yakni 0,562. Berarti bahwa tidak signifikannya pengaruh NPL terhadap kesulitan keuangan pada perbankan yang terdaftar pada $\mathrm{BEI}$ ( $\mathrm{HO}$ diterima, $\mathrm{Ha}_{5}$ ditolak). Hal ini tidak konsisten dengan penelitian Vidyarto Nugroho (2012) yang menyatakan LDR berpengaruh signifikan terhadap probabilitas kebangkrutan bank di Indonesia. LDR menunjukkan seberapa jauh kemampuan bank dalam membayar kembali penarikan dana yang dilakukan deposan dengan mengandalkan kredit yang diberikan sebagai sumber likuiditas (Dendawijaya, 2009). Hal ini sesuai dengan penelitian Almilia dan Winny Herdiningtyas (2005) Rasio LDR (Loan to Deposit Ratio) digunakan untuk menilai likuiditas suatu bank yang dengan cara membagi jumlah kredit yang diberikan oleh bank terhadap dana pihak ketiga. Semakin tinggi rasio ini, makin rendahnya kemampuan likuiditas bank, sehingga kemungkinan suatu bank dalam kondisi bermasalah akan semakin besar

Rasio LDR memiliki koefisien regresi 0,024 hal ini menunjukkan bahwa rasio LDR berpengaruh positif terhadap kondisi kesulitan keuangan yang artinya semakin tinggirendahLDRkemungkinan bank dalam kondisi bermasalah semakin kecil. Nilai positif pada koefisien regresi LDR konsisten dengan penelitian Santoso dalam Penny Mulyaningrum (2008), demikian pula sesuai dengan hipotesis awal yang diajukan pada penelitian ini (positif).

Implikasi LDR terhadap pihak manajemen perbankan disarankan tetap memperhatikan rasio LDR meskipun dalam penelitian ini LDR tidak signifikan, namun memiliki kesamaan koefisien tanda yakni positif. LDR ini merupakan penilaian yang sering digunakan oleh analis keuangan maupun calon investor dalam menilai kinerja bank. Penilaian ini melihat kemampuan perbankan dalam menjaga likuiditas dalam kapasitas yang memadai dan kecukupan manajemen risiko dalam likuiditas.

\section{BOPO sebagai prediktor positif kesulitan keuangan bank yang terdaftar di BEI}

Variabel bebas BOPO memiliki tingkat signifikansi lebih besar dari 0,05, yakni 0,612, berarti bahwa tidak signifikannya pengaruh BOPO terhadap kesulitan keuangan pada 
perbankan yang terdaftar pada $\mathrm{BEI}$ ( $\mathrm{H} 0$ diterima, $\mathrm{Ha}_{6}$ ditolak). Hal ini tidak konsisten dengan penelitian Penelitian Almilia dan Herdiningtyas (2010) menunjukkan BOPO berpengaruh positif signifikan terhadap kondisi kesulitan keuangan. Rasio BOPO digunakan untuk mengukur tingkat efisiensi dan kemampuan bank dalam melakukan kegiatan operasinya (Dendawijaya, 2009).

Rasio BOPO memiliki koefisien regresi 0,36 hal ini menunjukkan bahwa rasio BOPO berpengaruh positif terhadap kondisi kesulitan keuangan yang artinya semakin tinggi rasio BOPO kemungkinan bank dalam kondisi bermasalah semakin besar. Nilai positif pada koefisien regresi BOPO konsisten dengan penelitian Penelitian Almilia dan Herdiningtyas. Penelitian Almilia dan Herdiningtyas (2010) BOPO berpengaruh positif signifikan terhadap kondisi kesulitan keuangan, demikian pula sesuai dengan hipotesis awal yang diajukan pada penelitian ini (positif).

Implikasi rasio BOPO terhadap pihak manajemen perbankan diharapkan tetap memperhatikan rasio ini meskipun dalam penelitian ini BOPO tidak signifikan, namun koefisien dalam penelitian ini yakni searah ( positif). BOPO yang menurun menandakan bahwa manajemen melakukan kebijakan dalam meminimalisasi biaya, sehingga dapat meningkatkan laba. Laba yang meningkat berdampak positif bagi perusahaan smakin memiliki kredibilitas dimata publik.

GWM Primer sebagai prediktor negatif kesulitan keuangan bank yang terdaftar di BEI

Variabel bebas GWM primer memiliki tingkat signifikansi lebih kecil dari 0,05 yakni 0,021, hal ini berarti bahwa ada pengaruh signifikan rasio GWM primer terhadap kesulitan keuangan pada perbankan yang terdaftar pada BEI ( $\mathrm{HO}$ ditolak, $\mathrm{Ha}_{7}$ diterima). Hal ini konsisten dengan jumlah dana minimum yang wajib dipelihara oleh bank yang ditetapkan oleh Bank Indonesia sebesar persentase tertentu dari DPK (Peraturan Bank Indonesia Nomor: 15/15/Pbi/2013). Guna suatu ketika bank mengalami kesulitan keuangan bank tersebut dapat meminjam langsung kepada BI.

Rasio GWM mempunyai pengaruh signifikan terhadap kondisi keuangan yang bermasalah dan pengaruhnya negatif artinya semakin rendah rasio ini, kemungkinan bank dalam kondisi bermasalah semakin besar rasio GWM primer memiliki koefisien regresi $-0,900$ hal ini menunjukkan bahwa rasio GWM primer berpengaruh negatif terhadap kondisi kesulitan keuangan yang artinya semakin rendah rasio GWM primerkemungkinan bank dalam kondisi bermasalah semakin besar. Nilai negatif pada koefisien regresi GWM primer konsisten dengan hipotesis yang diajukan yakni bernilai negatif.

Implikasi rasio GWM primer terhadap pihak manajemen perbankan tetap harus memperhatikan rasio GWM primer dalam melakukan kinerjanya, dikarenakan dalam penelitian variabel GWM primer berpengaruh signifikan, dan memiliki kesamaan koefisien 
tanda negatif. Pengaruh makin besarnya GWM akan diikuti pula dengan besarnya likuiditas bank dijamin $\mathrm{BI}$, sehingga memperkecil risiko perbankan mengalami kesulitan keuangan.

\section{Kesimpulan}

Berdasarkan hasil penelitian dan pembahasan dapat dikemukakan simpulan sebagai berikut: (1) Sektor perbankan (sampel penelitian) rata-rata memiliki kesulitan keuangan (financial distress) yang rendah, artinya selama tahun analisis kinerja perbankan cukup baik; (2) Variabel CAR, ROE, NIM, LDR, dan BOPO tidak signifikan sebagai prediktor terhadap financial distress perbankan yang listing di BEl; (3) Variabel NPL dan GWM primer signifikan sebagai prediktor financial distress perbankan yang listing di BEI.

\section{Saran}

Sehubungan hasil penelitian dan pembahasan dapat dikemukakan saran sebagai berikut: (1) Walaupun CAR, ROE, NIM, LDR, dan BOPO tidak signifikan sebagi prediktor financial distress, tentunya tetap menjadi pertimbangan pihak bank guna melakukan kebijakan - kebijakan khususnya kebijakan terkait dengan fenomena terjadinya finansial distress; (2) Peneliti selanjutnya agar dapat melengkapi analisis fundamental dan menambah dengan analisis teknikal dalam analisis financial distress; (3) Selain itu populasi pada penelitian - penelitian selanjutnya juga dapat ditambahkan seperti bank devisa dan bank asing

\section{Daftar Referensi}

Almilia \& Herdiningtyas. 2005. Analisis Rasio CAMEL Terhadap Prediksi Kondisi Bermasalah Pada Lembaga Perbankan Periode 2000-2002.Jurnal Akutansi danKeuangan. Vol.7, No.2.

Altman, Edward I, 1968. Financial Ratios, Discriminant Analysis and ThePrediction of Corporate Bankruptcy.The Journal of Finance, vol.23 No.4, pp.589-609.

Bank Indonesia. 2007.Surat Edaran BI No.07/10/DPNP tanggal 31 Maret 2007 tentang Perubahan atas Surat Edaran Bank Indonesia No.3/30/DPNP tanggal 14 Desember 2001. Jakarta.

2010. Peraturan BI Nomor 12/19/PBI/2010 tentang Giro Wajib Minimum Bank Umum pada Bank Indonesia dalam Rupiah dan Valuta asing. Jakarta.

Beaver, William H. 2006. Financial Ratios as Predictors of Failure.EmpiricalResearch in Accounting.Selected Studies and Discussions. Preston KMears and By John Neter 12 (3) : 71-127.

Dendawijaya, Lukman. 2009. Manajemen Perbankan. Ghalia Indonesia: Jakarta.

Ghozali, Imam.2009. Aplikasi Analisis Multivariate Dengan Program SPSS, Edisi, Keempat. Semarang: Badan Penerbit Universitas Diponegoro. 
Kurniasari. Christiana. 2013. Analisis Pengaruh Rasio Camel Dalam Memprediksi financial Distress Perbankan Indonesia. Tidak Diterbitkan. Skripsi. Semarang: Universitas Diponegoro.

Lestari, V.D, 2009. Analisis Tingkat Kesehatan Bank - Bank Pemerintah Dengan Menggunakan Metode CAMELS Dan Analisis Diskriminan Periode 2006 - 2008. Tesis. Depok: Universitas Gunadarma.

Penny. Mulyaningrum. 2008. "Pengaruh Rasio Keuangan Terhadap Kebangkrutan Bank di Indonesia."Tidak Diterbitkan. Tesis. Semarang: Universitas Diponogoro.

Prasetyo, E.A. 2011. Faktor - faktor yang memengaruhi Kondisi Financial Distress Perusahaan Perbankan yang Listing di BEI Tahun 2006 - 2008. Tidak Dipublikasikan. Skripsi. Semarang: Universitas Diponogoro.

Ramadhani dan Lukviarman, Niki. 2009. Perbandingan Analisis Prediksi Kebangkrutan Menggunakan Model Altman Pertama, Altman Revisi, Dan Altman Modifikasi Dengan Ukuran Dan Umur Perusahaan Sebagai Variabel Penjelas (Studi Pada Perusahaan Manufaktur Yang Terdaftar Di Bursa Efek Indonesia).Jurnal Siasat Bisnis 2(1) : 47 - 56

Santoso, Wimboh. Hadad, Muliaman D dan Sarwedi. 2008.Model Prediksi Kepailitan Bank Umum di Indonesia, Banking Research and Regulation. Bank Indonesia.

Siamat, Dahlan. 2006. Manajemen Lembaga Keuangan. Penerbit Fakultas Ekonomi Universitas Indonesia: Jakarta

Vidyanto Nugroho. 2012. Pengaruh Camel Dalam Memprediksi Kebangkrutan Bank. Jurnal Akuntansi 16 (2) : 145-161.

Wilopo. 2011. Prediksi Kebangkrutan Bank. Jurnal Riset Akuntansi Idonesia . 4 (2) : 184-19 